\title{
Supplementation with Resveratrol, Piperine and Alpha-Tocopherol Decreases Chronic Inflammation in a Cluster of Older Adults with Metabolic Syndrome
}

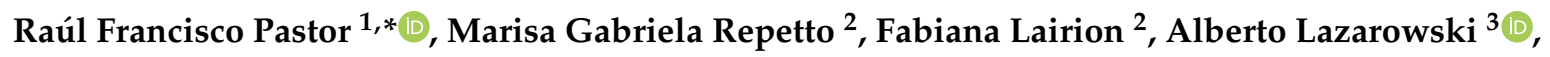 \\ Amalia Merelli ${ }^{3}$, Zulma Manfredi Carabetti ${ }^{1}$, Isabel Pastor ${ }^{1}$, Elena Pastor ${ }^{1}$, \\ Laura Valeria Iermoli ${ }^{1}$, Carlos Amadeo Bavasso ${ }^{1}$ and Roberto Héctor Iermoli ${ }^{1}$ \\ 1 Unidad Polifenoles, Vino y Salud, Cuarta Cátedra de Medicina, Hospital de Clínicas “José de San Martín” \\ Facultad de Medicina, Universidad de Buenos Aires, City of Buenos Aires C1120AAF, Argentina; \\ zulmamanfredi@tiempomedico.com.ar (Z.M.C.); ipastor@hospitaldeclinicas.uba.ar (I.P.); \\ epastor@hospitaldeclinicas.uba.ar (E.P.); lauraiermoli@gmail.com (L.V.I.); \\ analisisintegrales@hotmail.com (C.A.B.); riermoli@fmed.uba.ar (R.H.I.) \\ 2 Departamento de Físicoquímica y Química Analítica, Facultad de Farmacia y Bioquímica, Universidad de \\ Buenos Aires; Instituto de Bioquímica y Medicina Molecular (IBIMOL) Consejo Nacional de Ciencia y \\ Tecnología (UBA-CONICET), City of Buenos Aires C1113AAD, Argentina; mrepetto@ffyb.uba.ar (M.G.R.); \\ flairion@ffyb.uba.ar (F.L.) \\ 3 Departamento de Bioquímica Clínica, Facultad de Farmacia y Bioquímica, Universidad de Buenos Aires, \\ Instituto de Fisiopatología y Bioquímica Clínica (INFIBIOC), Buenos Aires C1113AAD, Argentina; \\ nadiatom@ffyb.uba.ar (A.L.); amerelli@ffyb.uba.ar (A.M.) \\ * Correspondence: rpastor@fmed.uba.ar; Tel.: +54-9-11-4411-4806
}

Received: 16 September 2020; Accepted: 8 October 2020; Published: 15 October 2020

\begin{abstract}
Metabolic Syndrome (MetS) is increasing worldwide regardless of culture, genetic, gender, and geographic differences. While multiple individual risk factors, such as obesity, hypertension, diabetes, and hyperlipidemia, can cause cardiovascular disease (CVD), it is the intercurrence of these risk factors that defines MetS as a cluster that creates an environment for atherosclerosis and other manifestations of CVD. Despite the advances in the knowledge and management of each of the components of MetS, there are two molecular biology processes, chronic inflammation and oxidative stress, which are still underdiagnosed and undertreated. In order to assess the effect of a dietary supplement on chronic inflammation in MetS, we conducted a clinical trial with volunteers receiving a formula composed of resveratrol, piperine and alpha tocopherol (FRAMINTROL ${ }^{\circledR}$ ), together with their habitual treatment, for three months. The inflammatory state was evaluated by ultrasensitive $C$ reactive protein (US CRP) and ferritin in plasma, and oxygen consumption and chemiluminescence in neutrophils. The results showed that ferritin decreased by 10\% $(p<0.05)$, US-CRP by $33 \%(p<0.0001)$, oxygen consumption by $55 \%(p<0.0001)$, and spontaneous chemiluminiscence was by $25 \%(p<0.005)$ after treatment. As far as we know, this is the first study showing a chronic inflammation decrease in MetS patients due to the administration of a biopower Resveratrol-piperine and alpha tocopherol dietary supplement together with conventional therapy.
\end{abstract}

Keywords: metabolic syndrome; chronic inflammation; resveratrol; piperine; alpha-tocopherol

\section{Introduction}

According to the World Health Organization, obesity, a common denominator of MetS, has in general increased three-fold worldwide since 1975. Lifestyle changes, such as a marked reduction in physical activity levels and an increased consumption of high-calorie foods, have been conducive to the increased prevalence of obesity. 
Epidemiological data from 2016 show that $39 \%$ of individuals over 18 were overweight and $13 \%$ were obese. It has been shown that overweight and obesity are risk factors for the noncommunicable chronic diseases (NCCDs) included in MetS. Consequently, the deterioration in quality of life for both patients and families added to the high medical and social costs are a great concern for health care systems.

MetS is a clinical disorder that is defined by the co-occurrence of other CVD risk factors, such as central obesity, abnormalities of glucose metabolism or diabetes, dyslipidemia and arterial hypertension. No standardized global data are available on the prevalence of MetS because diagnostic criteria vary in different guidelines [1]. In Argentina, a systematic review carried out with urban populations, with a mean age of 46.2 , found a prevalence of MetS of $27.5 \%$ for both genders, higher in males than females, at $29.4 \%$ vs. $27.4 \%$ respectively [2].

In another systematic review conducted in Latin American countries, the prevalence reached $24.9 \%$ and was slightly higher in females $(25.3 \%)$ than in males $(23.2 \%)$; individuals over the age of 50 had the highest prevalence [3].

A meta-analysis conducted in China found that the general prevalence of MetS in individuals over 15 years of age was $24.5 \%$, of which $19.2 \%$ were males and $27 \%$ were females. This prevalence increased with aging, being at around 32.4\% in individuals over 60 [4].

A systematic review conducted in Brazil found an average prevalence of $29.6 \%$, and the indigenous and rural populations were the most and the least affected with $65.3 \%$ and $14.9 \%$, respectively [5]. In the USA, based on data from the National Health and Nutrition Examination Survey (NHANES) between 2003-2012, the prevalence of MetS was at 33\%, higher in females than in males, at $35.6 \%$ vs. $30.3 \%$ respectively [6].

A systematic review conducted in Middle East countries found an average prevalence of MetS of $25 \%$ [7]. The PROMETS trial in Portugal found a prevalence of 36.5\%, and MetS was slightly more common in females than in males, at $40.7 \%$ vs. $39 \%$ respectively [8].

It has been well proven that obesity features a chronic low grade inflammatory state and that the cumulative molecular damage caused by the oxidative metabolism plays a key role in the pathogenesis of age-related conditions, also contributing to increased inflammation and oxidative stress levels $[9,10]$. These two processes are interdependent and often share signaling pathways and biochemical processes that accelerate aging from the onset of chronic diseases included in MetS. Redox homeostasis is maintained in physiological situations at the expense of the antioxidant regulation of the concentrations of oxidant species, and in terms of molecular biology it involves intracellular protein signaling and transcription mechanisms [11]. When these mechanisms are altered or absent, an excessive accumulation of biomarkers of inflammation and oxidative stress occurs, with byproducts of biomolecular oxidation, and signaling pathways are therefore altered [11,12].

Based on these findings, several clinical trials have investigated whether vitamin antioxidants might prevent NCCDs $[13,14]$. However, the obtained results were generally disappointing because, although some of the studies found benefits for health, others did not obtain any results or even found deleterious effects [15]; this is because, in some cases, biology uses free radicals as signaling pathways, and massive elimination might partly account for this failure, leading to what is known as the antioxidant paradox of vitamins [16-18].

The MetS is one of the maximum expressions of chronic inflammation, as several chronic inflammatory conditions coexist. This inflammatory syndrome, which accelerates aging, is still generally underdiagnosed and undertreated in medical practice. For this reason, the aim of our research was to assess the effect of a Resveratrol + Piperine + Alpha-tocopherol (FRAMINTROL ${ }^{\circledR}$ ) dietary supplement on chronic inflammation in MetS.

\section{Materials and Methods}

Between May and December 2019, we publicly invited out-patients with MetS to participate in a clinical trial approved by the Ethics Committee of the University of Buenos Aires, Clinics Hospital. 
These included twenty-two patients (13 males and nine females), mean age $68 \pm 4.7$ years, diagnosed with MetS according to the global harmonized definition of having three of the five following characteristics: [19] 1. Blood glucose levels over $100 \mathrm{mg} / \mathrm{dL}$ or drug therapy for high blood glucose levels; 2. HDL Cholesterol $<40 \mathrm{mg} / \mathrm{dL}$ in males or $<50 \mathrm{mg} / \mathrm{dL}$ in women, or drug therapy for low HDL cholesterol levels; 3. Blood triglycerides $>150 \mathrm{mg} / \mathrm{dL}$ or drug therapy for high triglyceride levels; 4. Waist circumference $>102 \mathrm{~cm}$ for males or $>88 \mathrm{~cm}$ for females; and 5. Blood pressure $>130 / 85 \mathrm{mmHg}$ or antihypertensive drug therapy.

At the first interview, the participants of this clinical trial \#26122018 approved by the Ethics Committee of the "José de San Martín" Clinics Hospital University of Buenos Aires were presented, in accordance with the 1964 Helsinki Declaration and the later updated versions of Tokyo (1975), Venetia (1983), Hong Kong (1989), Somerset West (1996), Edinburgh (2000), Washington (2002), Tokyo (2004), Korea (2008) and Brazil (2013), and also according to the personal data protection Act $\mathrm{N}^{\circ}$ 25.326; then, the inclusion criteria were analyzed, and informed consent was obtained.

The Ethics Committee, through the approved protocol, established as a condition that the background treatments for NCCDs, oral hypoglycemic agents, antihypertensives or medical therapy for dyslipidemia should not be suspended and should remain unchanged during the trial. The average baseline data of all the patients are included in Table 1.

Table 1. Patient average baseline data.

\begin{tabular}{ll}
\hline Patients (Male-Female) & $22(\mathrm{M} \mathrm{13-F} \mathrm{9)}$ \\
Age (years) & $68 \pm 4.7$ \\
Weight $(\mathrm{kg})$ & $82 \pm 17.5$ \\
Body Mass Index $\left(\mathrm{kg} / \mathrm{m}^{2}\right)$ & $29.25 \pm 3.4$ \\
Systolic blood pressure $(\mathrm{mmHg})$ & $135 \pm 25.85$ \\
Diastolic blood pressure $(\mathrm{mmHg})$ & $86 \pm 18.32$ \\
Waist circumference $(\mathrm{cm})$ & $109 \pm 23.30$ \\
Blood glucose $(\mathrm{mg} / \mathrm{dL})$ & $103 \pm 21$ \\
HDL Cholesterol $(\mathrm{mg} / \mathrm{dL})$ & $57.95 \pm 12.32$ \\
Triglycerides $(\mathrm{mg} / \mathrm{dL})$ & $126 \pm 26.86$ \\
Plasma ferritin $(\mathrm{ng} / \mathrm{mL})$ & $198.45 \pm 38.11$ \\
Ultrasensitive C reactive protein $(\mathrm{mg} / \mathrm{L})$ & $4.10 \pm 0.87$ \\
Oxygen consumption $\left(\mathrm{nmol} \mathrm{O} / \mathrm{min} / 10^{6}\right.$ cells) & $13 \pm 2$ \\
Chemiluminescence $(\mathrm{cps} / \mathrm{mL}$ cells $)$ & $134 \pm 47$ \\
\hline
\end{tabular}

As the participation of the five different CVD risk factors within MetS varies among patients, we presented, as shown in Table 2, the percentage of each condition in MetS. Hypertension was the most prevalent entity.

Table 2. Relative participation and percentage of the five CVD risk factors in the MetS patients.

\begin{tabular}{lllllll}
\hline & $\begin{array}{l}\text { Arterial } \\
\text { Hypertension }\end{array}$ & $\begin{array}{l}\text { Waist } \\
\text { Circumf }\end{array}$ & Triglycerides & $\begin{array}{l}\text { HDL } \\
\text { Cholesterol }\end{array}$ & $\begin{array}{l}\text { High Glucose } \\
\text { or Diabetes }\end{array}$ & $\begin{array}{l}\text { Patients/CVD } \\
\text { Risk Factors } \\
\text { in MetS }\end{array}$ \\
\hline Patients & $20 / 22$ & $19 / 22$ & $18 / 22$ & $18 / 22$ & $16 / 22$ & $10 / 5$ \\
& $91 \%$ & $86 \%$ & $82 \%$ & $82 \%$ & $73 \%$ & $5 / 4$ \\
& & & & & $7 / 3$ \\
\hline
\end{tabular}

Tables 3-5 show the clinical data of each patient at the beginning of the trial, where the different MetS expressions can be observed. As can be seen, some risk factors were controlled by treatment and others were not. 
Table 3. Baseline data of seven MetS patients with 3/5 CVD risk factors. The shadowed cells indicate the treated conditions. BP, Blood Pressure: $(\mathrm{mmHg})$; WC, waist circumference $(\mathrm{cm})$; TG: Triglyderides (mg/dL); HDL Chol., HDL cholesterol (mg/dL); BG, Blood Glucose (mg/dL).

\begin{tabular}{cccccc}
\hline Patient ID & BP & WC & TG & HDL Col. & BG \\
\hline HB & $180 / 100$ & 114 & 71 & 48 & 97 \\
CF & $120 / 80$ & 88 & 105 & 77 & 99 \\
MG & $148 / 86$ & 93 & 64 & 51 & 91 \\
PH & $105 / 78$ & 107 & 90 & 81 & 106 \\
HL & $116 / 60$ & 98.5 & 169 & 45 & 90 \\
RS & $130 / 90$ & 110 & 90 & 61 & 90 \\
ES & $130 / 96$ & 101 & 133 & 40 & 98 \\
\hline
\end{tabular}

Table 4. Baseline data from five MetS patients with $4 / 5$ CVD risk factors. The shadowed cells indicate the conditions under treatment.

\begin{tabular}{cccccc}
\hline Patient ID & BP & WC & TG & $\begin{array}{c}\text { HDL } \\
\text { Chol. }\end{array}$ & BG \\
\hline BH & $150 / 90$ & 114 & 79 & 39 & 105 \\
AD & $160 / 100$ & 99 & 57 & 77 & 101 \\
LV & $120 / 80$ & 104 & 107 & 76 & 90 \\
EV & $130 / 80$ & 123 & 282 & 39 & 89 \\
MG & $100 / 86$ & 93 & 64 & 51 & 91 \\
\hline
\end{tabular}

Table 5. Baseline data from 10 MetS patients with 5/5 CVD risk factors. All of them were receiving treatment for their baseline conditions.

\begin{tabular}{cccccc}
\hline Patient ID & BP & WC & TG & $\begin{array}{c}\text { HDL } \\
\text { Chol. }\end{array}$ & BG \\
\hline JB & $140 / 90$ & 112 & 65 & 60 & 105 \\
RB & $140 / 92$ & 140 & 131 & 37 & 136 \\
SN & $120 / 70$ & 99 & 50 & 66 & 99 \\
CL & $160 / 84$ & 128 & 155 & 79 & 116 \\
JP & $138 / 86$ & 128 & 238 & 64 & 104 \\
AS & $120 / 80$ & 114.5 & 354 & 30 & 111 \\
MS & $130 / 90$ & 119 & 100 & 68 & 119 \\
ET & $130 / 90$ & 110 & 202 & 43 & 110 \\
LA & $140 / 98$ & 95 & 104 & 89 & 110 \\
HA & $170 / 100$ & 103 & 58 & 54 & 102 \\
\hline
\end{tabular}

Patients started treatment after a two-week washout of dietary supplements (antioxidants, vitamins or minerals), control visits were scheduled for 30,60 and 90 days, and the treatment included two pills per day of a biopower formula of resveratrol $50 \mathrm{mg}+$ piperine $5 \mathrm{mg}+$ alpha tocopherol $25 \mathrm{mg}$ (FRAMINTROL ${ }^{\circledR}$ ), one with each main meal.

According to the design of the study, each patient was their own matched control, in order to prevent interindividual variables and the bioavailability of the active ingredient. Blood and urine tests were performed twice, at the beginning and at the end of the treatment. The following parameters in plasma were assessed: glycemia, HDL Cholesterol, triglycerides, ferritin, US CRP, and the oxygen consumption and spontaneous chemiluminescence activity in isolated neutrophils.

Biochemical measurements were obtained using a diagnostic kit from Roche Laboratories, measured with Hitach Covas C311. Hematological measurements were made using LABIX reactive kits measured with SEAC HECO. 


\subsection{Samples and PMN Isolation}

The venous blood samples were obtained with heparin. PMNs were isolated from blood samples in the Hematology Laboratory of the Clinical Biochemistry Department of "José de San Martín" Clinics Hospital using Ficoll-Hypaque method and exposed to hypotonic shock with a sterile $\mathrm{NaCl}$ solution $(0.2 \% \mathrm{w} / \mathrm{v})$ and the same volume of sterile $\mathrm{NaCl}$ solution $(1.6 \% \mathrm{w} / \mathrm{v})$. This suspension of PMNs was centrifuged for $10 \mathrm{~min}$ at $450 \mathrm{~g}$ at $20^{\circ} \mathrm{C}$, the supernatant fluid was discarded, and the pellet was resuspended in $10 \mathrm{~mL}$ of sterile RPMI 1640 medium at $37^{\circ} \mathrm{C}$ [20].

\subsection{Neutrophils Viability}

PMNs' viability was tested with a vital staining Trypan Blue solution $(0.4 \%)$, and only cell suspensions with a viability $>95 \%$ were used.

\subsection{PMNs Count and Viability}

Total and differential cell accounts of viable PMNs in suspension, were developed using the Sysmex XP-300 ${ }^{\mathrm{TM}}$ Automated Hematology Analyzer (Sysmex ${ }^{\circledR \circledR}$ XN-Series, Chuo-ku, Kobe, Japan) Sysmex Corporation, Chuo-ku, Kobe, Japan, in a mode to distinguish the mononuclear (MN) cells from neutrophils. These counts were confirmed manually with Neubauer's chamber, using a 1/400 dilution of the PMNs suspension in Turk's solution (1-2\% acetic acid with aqueous methylene blue). PMNs' viability was measured with an equal volume of Trypan Blue solution (T8154-Sigma-Aldrich) using a $1 / 100$ dilution of the abovementioned neutrophil suspension. The mononuclear cells/neutrophils ratio as well as cell viability was determined before and after each experiment. PMN samples were sent to the School of Pharmacy and Biochemistry for oxygen consumption and chemiluminescence.

\subsection{PMN Oxygen Consumption}

PMN oxygen uptake was determined polarographically by high resolution respirometry, using a Clark-type electrode (Hasantech Oxygraph System DW1, Norfolk, England) Hasantech Instruments Ltd, Norfolk, England, thermostated at $37^{\circ} \mathrm{C}$, with human PMN $\left(10^{6} / \mathrm{mL}\right)$ in PBS supplemented with $0.9 \mathrm{mM} \mathrm{CaCl}_{2}, 0.5 \mathrm{mM} \mathrm{MgCl}_{2}$ and $7.5 \mathrm{mM}$ glucose (PBSG). For the assay, respiratory buffer (for a $1 \mathrm{~mL}$ final volume) was placed in the electrode chamber, and the rate of oxygen consumption was calculated from the initial time course and expressed as nmol of oxygen $/ \mathrm{min} / 10^{6}$ cells [21].

\subsection{PMN Chemiluminescence}

Spontaneous chemiluminescence in fresh PMNs was measured with a photon counter developed by Chance, Sies and Boveris (1979) in the Johnson Research Foundation of the University of Pennsylvania (Philadelphia, PA, USA). The results were expressed in cps/mL PMN (cps: counts per second, $1 \mathrm{cps}$ corresponds to about $10^{3}$ photons per second) [22-24].

\subsection{Statistics}

The statistical analysis was performed using the Student $t$-test for paired samples (Prim 7.0, GraphPad, San Diego, CA, USA). The Student $t$-test was selected to evaluate a single biomarker at a time in eight series of paired data (D0 vs. D90 for plasma ferritin and US CRP, in neutrophils, oxygen consumption and spontaneous chemiluminescence) for each patient before and after the intervention.

\section{Results and Discussion}

The 22 patients with MetS showed a good tolerance to the treatment with two pills a day of the Resveratrol $50 \mathrm{mg}+$ piperine $5 \mathrm{mg}+$ alpha-tocopherol $25 \mathrm{mg}\left(\right.$ FRAMINTROL $^{\circledR}$ ) formula, with no side effects.

The measurements of the inflammatory state appear in Table 6. The observed baseline and post-treatment variations were all beneficial, plasma ferritin levels decreased significantly by $10 \%$, 
and US CRP decreased in plasma by 33\%, evidencing a highly significant drop (Figures 1 and 2); in neutrophils, oxygen consumption decreased by $55 \%$ and spontaneous chemiluminescence by $25 \%$ after 90 days of treatment; both decreases were highly significant (Figures 3 and 4).

Table 6. Variables of the inflammatory state; in plasma: ferritin and US CRP, and in neutrophils: baseline and post-treatment (after 90 days of resveratrol, piperine y alpha-tocopherol) oxygen consumption and chemiluminescence.

\begin{tabular}{llllr}
\hline Biomarkers/ Basal vs. Final & \multicolumn{1}{c}{ Basal } & \multicolumn{1}{c}{ Final } & \multicolumn{1}{c}{$\boldsymbol{p}$} & \multicolumn{1}{c}{$\boldsymbol{\Delta} \%$} \\
\hline Plasma ferritin $(\mathrm{ng} / \mathrm{mL})$ & $198.45 \pm 38.11$ & $178.75 \pm 21.90$ & $<0.05$ & 10 \\
Oxygen consumption $\left(\mathrm{nmol} \mathrm{O}_{2} / \mathrm{min} / 10^{6}\right.$ cells) & $13 \pm 2$ & $6 \pm 1$ & $<0.0001$ & 55 \\
Ultrasensitive C reactive protein $(\mathrm{mg} / \mathrm{L})$ & $4.10 \pm 0.87$ & $2.74 \pm 0.59$ & $<0.0001$ & 33 \\
Chemiluminescence $(\mathrm{cps} / \mathrm{mL}$ cells) & $134 \pm 47$ & $100 \pm 22$ & $<0.005$ & 25 \\
\hline
\end{tabular}

250

\section{Plasma ferritin}

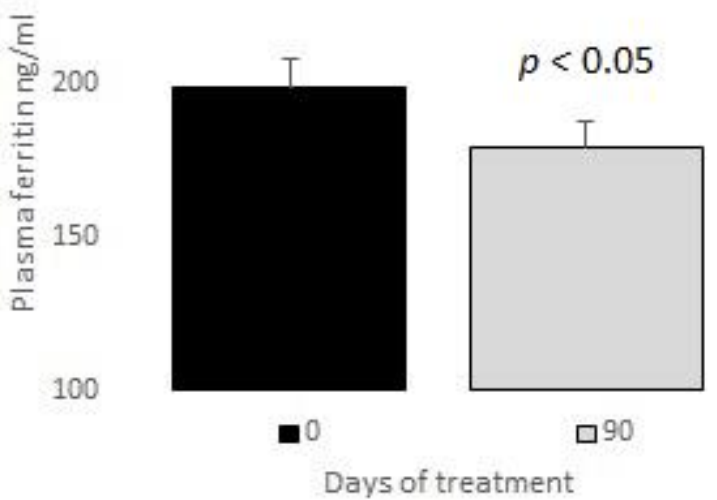

Figure 1. Plasma ferritin basal vs. 90 days of treatment with resveratrol, piperine and alpha-tocopherol in MetS patients.

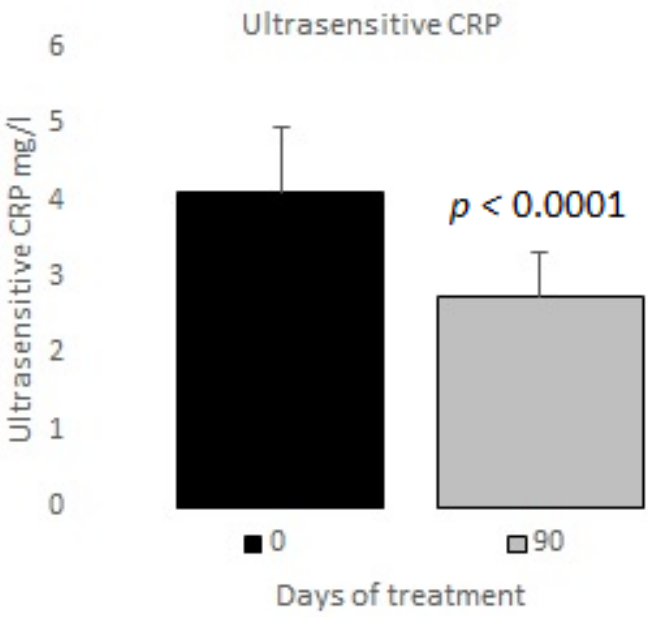

Figure 2. Ultrasensitive $C$ reactive protein basal vs. 90 days of treatment with resveratrol, piperine and alpha-tocopherol in MetS patients. 


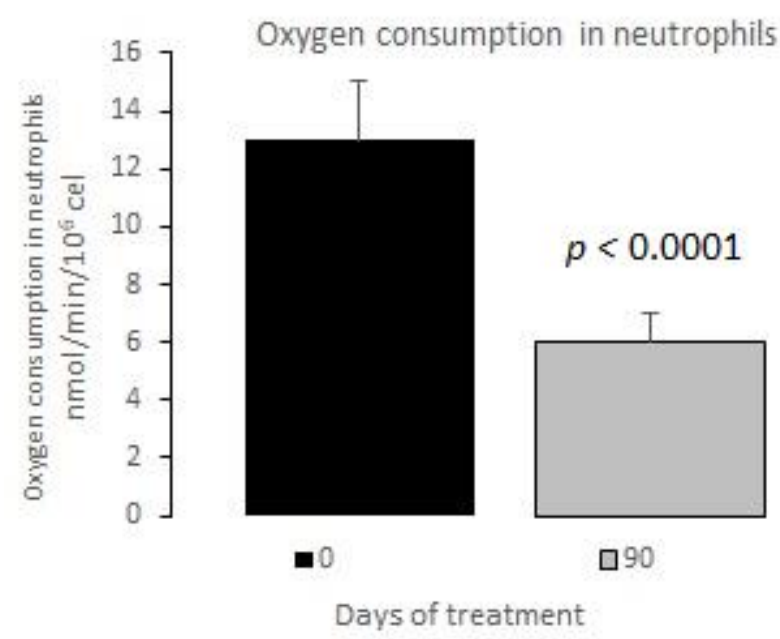

Figure 3. Oxygen consumption in neutrophils basal vs. 90 days of treatment with resveratrol, piperine and alpha-tocopherol in MetS patients.

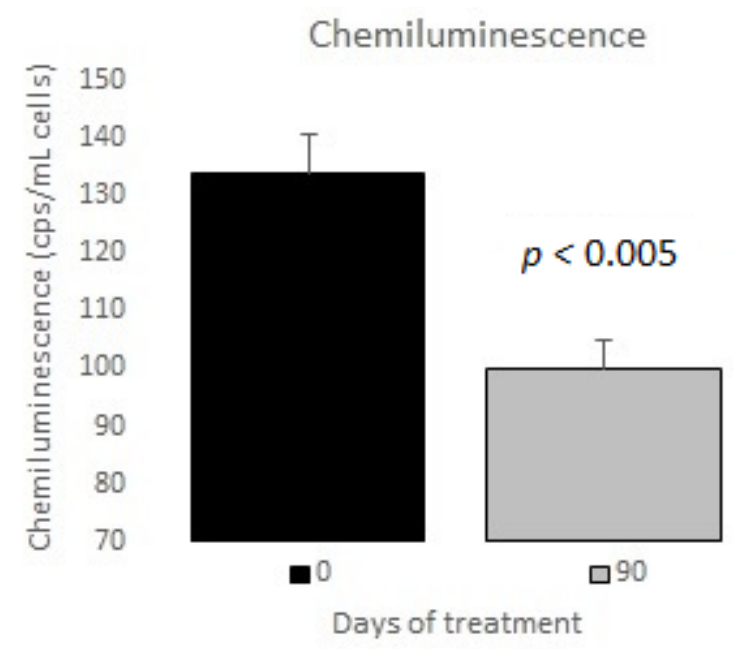

Figure 4. Chemiluminescence in neutrophils basal vs. 90 days of treatment with resveratrol, piperine and alpha-tocopherol in MetS patients.

Arterial hypertension is one of the most prevalent chronic cardiovascular conditions worldwide, and it was also the most prevalent in our MetS study population ( $91 \%$ of our patients) (Table 2$)$. It has been proven that low-grade chronic inflammation in arterial hypertension is present since the onset of the disease.

Although the etiology of essential arterial hypertension is still unknown, it has been found that both the innate and adaptive immune systems participate interdependently in the development of sustained high blood pressure, as well as in endothelial, kidney and target organ damage [25].

The phenomenon that triggers arterial hypertension has not been elucidated; however, it is known that pro-hypertensive stimuli such as Angiotensin II or excessive use of salt make lymphocytes T proinflammatory, which increases the release of inflammatory cytokines as well as oxidative stress levels $[26,27]$.

Increased metabolic activity in neutrophils in patients with MetS, as measured indirectly in oxygen consumption, might signal the intense activation of these inflammatory cells.

Obesity and diabetes were reported in $86 \%$ and $73 \%$ of the patients with MetS, respectively (Table 2). The physical effects related to the increase in adipose tissue caused by obesity provide many intrinsic signals produced by mechanical stress, hypoxia and adipocyte death that are able to initiate the inflammatory response. It has been shown that, as adipose tissue increases during 
obesity, inflammation and macrophage-innate immune cell-accumulation increase as well and that this infiltration reaches as much as $40 \%$ of all the adipose tissue cells [28,29].

The mechanical stress that triggers the inflammation in adipose tissue in obese individuals was first published in the early 1990s. This investigations showed that the adipose tissue of obese volunteers presented inflammatory changes with an increased release of cytokines mediated by tumor necrosis factor-alpha (TNF- $\alpha$ ), and this finding correlated with the inhibition of the insulin receptor substrate and consequently with an increased insulin resistance [30]. This finding has also been proven in basic research through reverse engineering, where TNF- $\alpha$ block increases sensitivity to insulin and improves glucose metabolism [30]. These findings confirm the significant activation of inflammatory processes by the innate and adaptive immune systems [31] in obesity, which constitute risk factors for increased insulin resistance and diabetes. In brief, lipid accumulation in adipose tissue in obese patients triggers an inflammatory response, resulting in an increased release of several cytokines [32,33]. It has also been evidenced that dyslipidemia induces an inflammatory response due to the activation of the immune system. Persistently high oxidized LDL cholesterol levels in plasma drive the production of interleukin 1 and 6 and therefore drive increases in US CRP levels [34]. High plasma ferritin is a biomarker of MetS. It was found that plasma ferritin values were correlated directly with different clinical expressions of MetS with three, four or five CVD risk factors [35,36]. In other words, there were more CVD risk factors with more plasma ferritin. Furthermore, it has been proven that, of all the MetS components, triglycerides and hyperglycemia are the variables that correlate the most with high plasma ferritin levels [37]. C reactive protein (CRP) is a protein of the pentraxin family, synthesized and released by endothelial cells in atherosclerotic plaques, hepatocytes, lymphocytes and macrophages, mainly in response to the increase of interleukin 7 (IL 7). It has been evidenced that US CRP in plasma is a biomarker of the inflammatory system in downstream MetS, and potentially a good biomarker for monitoring treatment results $[12,38,39]$.

In our study, the post-treatment decreases in plasma ferritin and US CRP reached $10 \%$ and $33 \%$, respectively (Figures 1 and 2). Thus, we believe that those variables are a potential tool for the clinical control of patients' outcomes.

Piperine is a bioactive alkaloid that gives black pepper its pungency. It has a broad spectrum of action in molecular biology, as an antioxidant, anti-inflammatory, antiangiogenic, antibacterial and immunomodulatory agent. Piperine may be naturally extracted from black pepper, with a $6 \%$ to $13 \%$ yield. Despite its many healthy properties, the use of piperine in human health is still limited due to its scarce availability and low solubility in water $[40,41]$. However, piperine has been shown to be a resveratrol booster, since the oral administration of a formula of piperine plus resveratrol $(10 / 100 \mathrm{mg} / \mathrm{kg}$, respectively) increases the bioavailability of resveratrol by $1544 \%$ when compared to resveratrol alone [42].

Alpha-tocopherol has been shown to have anti-inflammatory effects due to the decreased production of anti-inflammatory cytokines IL-1 beta IL- 6 and chemokine IL-8, together with the neutralization of alpha-TNF [43]. In obese individuals with and without diabetes, MetS is related to chronic systemic inflammation and low levels of alpha-tocopherol [44].

Neutrophils are the main intracellular source of superoxide anion $\left(\mathrm{O}_{2}{ }^{-}\right)$and hydrogen peroxide $\left(\mathrm{H}_{2} \mathrm{O}_{2}\right)$ in the inflammatory processes associated with human obesity and metabolic syndrome. These reactive oxygen species are mainly generated in PMN cells through NADPH oxidase complex activity. The rate of oxygen consumption measured in the Clark-type electrode indicates the electron transfer process for generating $\mathrm{O}_{2}{ }^{-}$and, therefore, $\mathrm{H}_{2} \mathrm{O}_{2}$ production. Spontaneous chemiluminescence is a useful approach for determining the occurrence of oxidative stress in either cells or tissues. Spontaneous chemiluminescence determination is a noninvasive, nondestructive indirect assay based on measuring the light emission from an excited state to a basal state of singlet oxygen $\left({ }^{1} \mathrm{O}_{2}\right)$ and peroxyl radicals (ROO), reactive and toxic products of phospholipid peroxidation. The number of emitted photons depends on the steady-state concentration of ${ }^{1} \mathrm{O}_{2}$, which is an indicator of the oxidative damage due to the final stage of the phospholipid oxidation in the chain reaction [22-24]. Resveratrol supplementation 
decreased the oxygen consumption and chemiluminescence levels in PMN of patients with MetS, indicating an anti-inflammatory and antioxidant effect after treatment (Figures 3 and 4).

\section{Conclusions}

Metabolic syndrome is a clinical entity with an increasing incidence and high prevalence worldwide, including several CVD risk factors; obesity, arterial hypertension, hyperglycemia and dyslipidemia have a common denominator, i.e., the chronic activation of the immune system, with inflammatory processes which damage the molecular biology and accelerate aging. In our research, we used a biopower formula containing three active ingredients: Resveratrol + Piperine + Alpha-Tocopherol (FRAMINTROL ${ }^{\circledR}$ ) in the management of patients with MetS.

The results of this treatment evidenced (1) a significant decrease in plasma ferritin levels and a highly significant decrease in US-CRP levels; (2) Plasma ferritin and US CRP might be good biomarkers of inflammation for the clinical follow up of patients with MetS; (3) A highly significant decrease in the oxygen consumption and spontaneous chemiluminescence of polymorphonuclear cells might be indicative of a remarkable drop in the proinflammatory metabolism of these cells of the immune system and of decreased levels of oxidant reactive species; (4) Reducing chronic inflammation in MetS patients should be a new prevention goal to decrease CVD risk factors.

Author Contributions: Conceptualization, R.F.P., M.G.R., Z.M.C. and R.H.I.; methodology, F.L., A.M., C.A.B., M.G.R.; patient selection, Z.M.C., I.P.; E.P., L.V.I.; software, I.P.; validation, R.F.P., M.G.R., A.L. and R.H.I.; formal analysis, R.F.P., M.G.R., Z.M.C.; investigation, R.F.P., M.G.R., Z.M.C. and R.H.I.; resources, TIEMPO MÉDICO grants; data curation, Z.M.C., I.P.; writing — original draft preparation, R.F.P.; writing—review and editing, R.F.P., M.G.P. and I.P.; visualization, M.G.R.; supervision, R.F.P., M.G.P., Alberto Lazarowski and R.H.I., Z.M.C.; project administration, Z.M.C., I.P.; funding acquisition, R.F.P. All authors have read and agreed to the published version of the manuscript.

Funding: This research received no external funding.

Acknowledgments: Our appreciation for the support and assistance of Mateo Conti Saguier, Eduardo Lombardi and Jerónimo Auzmendi.

Conflicts of Interest: The authors declare no conflict of interest.

\section{References}

1. Saklayen, M.G. The Global Epidemic of the Metabolic Syndrome. Curr. Hypertens. Rep. 2018, $20,12$. [CrossRef]

2. Diaz, A.; Espeche, W.; March, C.; Flores, R.; Parodi, R.; Genesio, M.; Sabio, R.; Poppe, S. Prevalencia del síndrome metabólico en Argentina en los últimos 25 años: Revisión sistemática de estudios observacionales poblacionales. Hipertensión y Riesgo Vascular 2018, 35, 64-69. [CrossRef]

3. Marquez-Sandoval, F.; Macedo-Ojeda, G.; Hörner, D.V.; Ballart, J.F.; Salas-Salvadó, J.; Vizmanos, B. The prevalence of metabolic syndrome in Latin America: A systematic review. Public Health Nutr. 2011, 14, 1702-1713. [CrossRef] [PubMed]

4. Li, R.; Li, W.; Lun, Z.; Zhang, H.; Sun, Z.; Kanu, J.S.; Qiu, S.; Cheng, Y.; Liu, Y. Prevalence of metabolic syndrome in mainland china: A meta-analysis of published studies. BMC Public Health 2016, 16, 296. [CrossRef]

5. Vidigal, F.d.C.; Bressan, J.; Babio, N.; Salas-Salvadó, J. Prevalence of metabolic syndrome in Brazilian adults: A systematic review. BMC Public Health 2013, 13, 1198.

6. Aguilar, M.; Bhuket, T.; Torres, S.; Liu, B.; Wong, R.J. Prevalence of the Metabolic Syndrome in the United States, 2003-2012. JAMA 2015, 313, 1973-1974. [CrossRef]

7. Ansarimoghaddam, A.; Adineh, H.A.; Zareban, I.; Iranpour, S.; Hosseinzadeh, A.; Kh, F. Prevalence of metabolic syndrome in Middle-East countries: Meta-analysis of cross-sectional studies. Diabetes Metab. Syndr. Clin. Res. Rev. 2018, 12, 195-201. [CrossRef]

8. Raposo, L.; Severo, M.; Barros, H.; Santos, A.C. The prevalence of the metabolic syndrome in Portugal: The PORMETS study. BMC Public Health 2017, 17, 555. [CrossRef] 
9. Reddy, P.; Lent-Schochet, D.; Ramakrishnan, N.; McLaughlin, M.; Jialal, I. Metabolic syndrome is an inflammatory disorder: A conspiracy between adipose tissue and phagocytes. Clin. Chim. Acta 2019, 496, 35-44. [CrossRef]

10. Taverne, Y.J.H.J.; Merkus, D.; Bogers, A.J.; Halliwell, B.; Duncker, D.J.; Lyons, T.W. Reactive Oxygen Species: Radical Factors in the Evolution of Animal Life. BioEssays 2018, 40, 1700158. [CrossRef]

11. Sies, H.; Berndt, C.; Jones, D.P. Oxidative Stress. Annu. Rev. Biochem. 2017, 86, 715-748. [CrossRef]

12. Chielle, E.O.; Gens, F.; Rossi, E.M. Oxidative, inflammatory and cardiometabolic biomarkers of clinical relevance in patients with metabolic syndrome. J. Bras. Patol. Med. Lab. 2018, 54, 213-219. [CrossRef]

13. Bjelakovic, G.; Nikolova, D.; Gluud, L.L.; Simonetti, R.G.; Gluud, C. Mortality in Randomized Trials of Antioxidant Supplements for Primary and Secondary Prevention. JAMA 2007, 297, 842-857. [CrossRef]

14. Zhang, S.M.; Cook, N.R.; Albert, C.M.; Gaziano, J.M.; Buring, J.E.; Manson, J.E. Effect of combined folic acid, vitamin B6, and vitamin B12 on cancer risk in women: A randomized trial. J. Am. Med. Assoc. 2008, 300, 2012-2021. [CrossRef] [PubMed]

15. Sesso, H.D.; Buring, J.E.; Christen, W.G.; Kurth, T.; Belanger, C.; MacFadyen, J.; Bubes, V.; Manson, J.E.; Glynn, R.J.; Gaziano, J.M. Vitamins E and C in the Prevention of Cardiovascular Disease in Men. JAMA 2008, 300, 2123-2133. [CrossRef] [PubMed]

16. Biswas, S.K. Does the Interdependence between Oxidative Stress and Inflammation Explain the Antioxidant Paradox? Oxidative Med. Cell. Longev. 2016, 2016, 5698931. [CrossRef] [PubMed]

17. Halliwell, B. The antioxidant paradox. Lancet 2000, 355, 1179-1180. [CrossRef]

18. Halliwell, B. The antioxidant paradox: Less paradoxical now? Br. J. Clin. Pharmacol. 2013, 75, 637-644. [CrossRef]

19. Alberti, K.; Eckel, R.H.; Grundy, S.M.; Zimmet, P.Z.; Cleeman, J.I.; Donato, K.A.; Fruchart, J.-C.; James, W.P.T.; Loria, C.M.; Smithjr, S.C. Harmonizing the Metabolic Syndrome. Circulation 2009, 120, 1640-1645. [CrossRef] [PubMed]

20. Kuhns, D.B.; Priel, D.A.L.; Chu, J.; Zarember, K.A. Isolation and Functional Analysis of Human Neutrophils. Curr. Protoc. Immunol. 2015, 111, 7-23. [CrossRef] [PubMed]

21. Valdez, L.B.; Boveris, A. Nitric Oxide and Superoxide Radical Production by Human Mononuclear Leukocytes. Antioxid. Redox Signal. 2001, 3, 505-513. [CrossRef]

22. Chance, B.; Sies, H.; Boveris, A. Hydroperoxide metabolism in mammalian organs. Physiol. Rev. 1979, 59, 527-605. [CrossRef]

23. Repetto, M. Clinical use of chemiluminescence assays for the determination of systemic oxidative stress. In Handbook of Chemiluminescent Methods in Oxidative Stress Assessment; Popov, I., Lewin, G., Eds.; Transword Research Network: Kerala, India, 2008; Volume 9, pp. 163-194. ISBN 978-81-7895-334-2.

24. Repetto, M.; Semprine, J.; Boveris, A. Lipid Peroxidation: Chemical Mechanism, Biological Implications and Analytical Determination. Lipid Peroxidation 2012, 1, 3-30. [CrossRef]

25. Bomfim, G.F.; Rodrigues, F.; Carneiro, F.S. Are the innate and adaptive immune systems setting hypertension on fire? Pharmacol. Res. 2017, 117, 377-393. [CrossRef] [PubMed]

26. Caillon, A.; Paradis, P.; Schiffrin, E.L. Role of immune cells in hypertension. Br. J. Pharmacol. 2018, 176, 1818-1828. [CrossRef]

27. Mikolajczyk, T.P.; Guzik, T.J. Adaptive Immunity in Hypertension. Curr. Hypertens. Rep. 2019, $21,68$. [CrossRef]

28. Zatterale, F.; Longo, M.; Naderi, J.; Raciti, G.A.; Desiderio, A.; Miele, C.; Beguinot, F. Chronic Adipose Tissue Inflammation Linking Obesity to Insulin Resistance and Type 2 Diabetes. Front. Physiol. 2020, 10, 1607. [CrossRef]

29. Weisberg, S.P.; McCann, D.; Desai, M.; Rosenbaum, M.; Leibel, R.L.; Ferrante, A.W. Obesity is associated with macrophage accumulation in adipose tissue. J. Clin. Investig. 2003, 112, 1796-1808. [CrossRef]

30. Hotamisligil, G.S.; Shargill, N.S.; Spiegelman, B.M. Adipose expression of tumor necrosis factor-alpha: Direct role in obesity-linked insulin resistance. Science 1993, 259, 87-91. [CrossRef]

31. Lumeng, C.N.; Saltiel, A.R. Inflammatory links between obesity and metabolic disease. J. Clin. Investig. 2011, 121, 2111-2117. [CrossRef]

32. Haase, J.; Weyer, U.; Immig, K.; Klöting, N.; Blüher, M.; Eilers, J.; Bechmann, I.; Gericke, M. Local proliferation of macrophages in adipose tissue during obesity-induced inflammation. Diabetologia 2013, 57, 562-571. [CrossRef] [PubMed] 
33. Raciti, G.A.; Spinelli, R.; Desiderio, A.; Longo, M.; Parrillo, L.; Nigro, C.; D’Esposito, V.; Mirra, P.; Fiory, F.; Pilone, V.; et al. Specific CpG hyper-methylation leads to Ankrd26 gene down-regulation in white adipose tissue of a mouse model of diet-induced obesity. Sci. Rep. 2017, 7, 43526. [CrossRef] [PubMed]

34. Jukema, R.A.; Ahmed, T.A.N.; Tardif, J.-C. Does low-density lipoprotein cholesterol induce inflammation? If so, does it matter? Current insights and future perspectives for novel therapies. BMC Med. 2019, 17, 197. [CrossRef]

35. Sun, L.; Franco, O.H.; Hu, F.B.; Cai, L.; Yu, Z.; Li, H.; Ye, X.; Qi, Q.; Ye, X.; Pan, A.; et al. Ferritin Concentrations, Metabolic Syndrome, and Type 2 Diabetes in Middle-Aged and Elderly Chinese. J. Clin. Endocrinol. Metab. 2008, 93, 4690-4696. [CrossRef]

36. Chen, L.; Li, Y.; Zhang, F.; Zhang, S.; Zhou, X.; Ji, L. Association of serum ferritin levels with metabolic syndrome and insulin resistance in a Chinese population. J. Diabetes Complicat. 2017, 31, 364-368. [CrossRef]

37. Suárez-Ortegón, M.F.; Ensaldo-Carrasco, E.; Shi, T.; McLachlan, S.; Fernández-Real, J.M.; Wild, S.H. Ferritin, metabolic syndrome and its components: A systematic review and meta-analysis. Atherosclerosis 2018, 275, 97-106. [CrossRef]

38. Devaraj, S.; Singh, U.; Jialal, I. The Evolving Role of C-Reactive Protein in Atherothrombosis. Clin. Chem. 2009, 55, 229-238. [CrossRef]

39. Devaraj, S.; Singh, U.; Jialal, I. Human C-reactive protein and the metabolic syndrome. Curr. Opin. Lipidol. 2009, 20, 182-189. [CrossRef]

40. Shityakov, S.; Bigdelian, E.; Hussein, A.A.; Hussain, M.B.; Tripathi, Y.C.; Khan, M.U.; Shariati, M.A. Phytochemical and pharmacological attributes of piperine: A bioactive ingredient of black pepper. Eur. J. Med. Chem. 2019, 176, 149-161. [CrossRef]

41. Chuchawankul, S.; Khorana, N.; Poovorawan, Y. Piperine inhibits cytokine production by human peripheral blood mononuclear cells. Genet. Mol. Res. 2012, 11, 617-627. [CrossRef]

42. Johnson, J.J.; Nihal, M.; Siddiqui, I.A.; Scarlett, C.O.; Bailey, H.H.; Mukhtar, H.; Ahmad, N. Enhancing the bioavailability of resveratrol by combining it with piperine. Mol. Nutr. Food Res. 2011, 55, 1169-1176. [CrossRef]

43. Singh, U.; Jialal, I. Anti-inflammatory Effects of $\alpha$-Tocopherol. Ann. N. Y. Acad. Sci. 2004, 1031, $195-203$. [CrossRef]

44. Skalicky, J.; Muzakova, V.; Kandar, R.; Meloun, M.; Roušar, T.; Palicka, V. Evaluation of oxidative stress and inflammation in obese adults with metabolic syndrome. Clin. Chem. Lab. Med. 2008, 46, 499-505. [CrossRef]

Publisher's Note: MDPI stays neutral with regard to jurisdictional claims in published maps and institutional affiliations.

(C) 2020 by the authors. Licensee MDPI, Basel, Switzerland. This article is an open access article distributed under the terms and conditions of the Creative Commons Attribution (CC BY) license (http://creativecommons.org/licenses/by/4.0/). 